\title{
КАРНАВАЛИЗАЦИЯ
}

\author{
И.В. Егорова
}

\section{ГЕРОИКА И СТРАХ КАК МОДУСЫ \\ ЧЕЛОВЕЧЕСКОГО СУЩЕСТВОВАНИЯ: РАННИЕ ПРОИЗВЕДЕНИЯ Э. ЮНГЕРА}

Аннотация. Творчество Эрнста Юнгера (1895-1978) как философствующего писателя в нашей стране известно мало. Что касается родины этого художника, то идеи, мысли, явные и неявные предсказания мастера слова вызывали большой интерес у общественности в довоенной и нынешней Германии. В свой творческий путь Э. Юнгер отправился в начале 20-х гг. ХХ в. Это было время экспериментов в социальной сфере, в области искусств, литературы, философии. Это был период бурного научно-технического, индустриального развития, попыток стремительного завоевания природы. Вместе с тем человек, уже примеривающий на себя мантию властелина мира, вдруг обнаруживал, что в действительности он оказался на обочине прокладываемого мировыми силами пути, что мир в своём собственном развитии далеко не всегда подчиняется человеку. В статье использованы подходы философской антропологии, которая обращена к анализу модусов человеческого существования. Это позволяет автору сопоставить героику с экзистенциальным опытом человеческого страха.

Э. Юнгер - весьма продуктивный и значимый философ. Его творчество плохо изучено, поскольку он после второй мировой войны считался по праву реакционным мыслителем. В 1920 г. появилась его книга «В стальных грозах", вторая книга "Борьба как внутреннее переживание», изданная в 1922 г., описывает войну в более широком масштабе, Юнгер также пишет роман «Буря». В 1925 г. уходит в отставку, в 1926 г. оставляет учёбу в университете, в 1927 г. переезжает в Берлин, где завязывает контакты с консервативно-революционным движением. Пишет статью для национал-социалистической газеты "Völkischer Beobachter» («Народный обозреватель») под названием «Revolution und Ideе» («Революция и идея»), в которой проповедует революционный национализм и необходимость диктатуры. Также публикуется в "Штандартах», "Арминии», "Наступлении». Сотрудничает с Фридрихом Хильшером, Эрнстом Никишем. Наряду с созданием множества политических очерков для различных журналов, Юнгер привнёс большой элемент политики в свои книги о войне. Третье издание «Стальных гроз» было выполнено в стиле радикального национализма, а в книгах "Лесок 125» («Das Wäldchen 125») и "Огонь и кровь» («Feuer und Blut») военный опыт ставится на службу радикальному революционному техницистскому национализму, осмысленному в рамках тоталитарной структуры. Большой очерк «Рабочий» ("Der Arbeiter», 1932) является кульминацией тоталитарных взглядов этого периода жизни, однако, к тому же времени Юнгер начинает разочаровываться в политике. Ключевые слова: философия, философская антропология, природа, рабочий, жизнь, политика, тоталитаризм, героика, страх, переживание.

Abstract. Ernst Junger (1895-1978) is very little known in our country even though he was a famous philosopher and writer. His ideas, thoughts, direct and indirect prophesies were of great interest to the society of the pre-war and today's Germany. Ernst Junger started his creative path in the early 20th of the XXth century. It was the time of expirements in the social sphere and spheres of art, literature and philosophy. It was also the period of intensive scientific, technological and industrial development and violent attempts to conquer nature. At the same time, while already trying on the gown of the world master, human has suddently discovered that he was on the margins of the path being made by global forces and that the world development does not always depend on human. In her research Egorova has used approaches of philosophical anthropology that analyzes modes of human existence. This has allowed the author to compare heroics to existential experience of human fear. Ernst Junger was a very productive and significant philosopher. His creative work is understudied because he was considered to be a reactionary philosopher after the war. In 1920 his book 'The Storm of Steel' was published. Being published in 1922, his second book 'Der Kampf als inneres Erlebnis' ('The Struggle as an Inner Experience') described the war in a broader sense. Ernst Junger also wrote another book 'Sturm' ('The Storm') shortly after. In 1925 Ernst Junger resigned his office, in 1926 he quit University and in 1927 he moved 
to Berlin where he joined the conservative revolutionary movement. He wrote the article for the national socialist newspaper 'Völkischer Beobachter' ('People's Observer') called 'Revolution und Idee' ('Revolution and Idea'), in which he discussed revolutionary nationalism and emphasized the need for dictatorship. He also published his articles in 'Standards', 'Arminius' and 'Attack'. He had contacts with Friedrich Hielscherand Ernst Niekisch. Apart from writing numerous political essays, Junger also spoke of politics in his books about the war. The third edition of 'The Storm of Steel' was written according to the principes of radical nationalism within the framework of the totalitarian structure. His essay 'Der Arbeiter' ('Worker') published in 1932 was the turning point of his totalitarian views, however, by that time Junger had already started to be rather disappointed in politics.

Key words: philology, philosophical anthropology, nature, worker, life, politics, totalitarianism, heroics, fear, emotional experience.

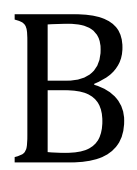

своем творчестве Э. Юнгер как раз исходит из признания необычного, многоликого своеобразия мировых процессов. Он считает, что действительность есть тайна, что мир, между предметами которого существуют невидимые, незримые связи, в действительности много богаче и разнообразнее, чем человек воспринимает его в обыденной, привычной жизни. Научиться распознавать эту необычность, как бы взрывать повседневность, фиксированность, заданность восприятия и видеть всю полноту богатств и чудес мира - в этом заключается жизненное искусство, задача человека [1, p. 106]. Все тайны лежат как бы на поверхности: требуется лишь найти определённый угол зрения, чтобы увидеть всё это. Какими в представлениях самого Юнгера возникают мир и человек?

Эрнст Юнгер, начавший свою творческую биографию с описания героики военных будней, в начале 30-х гг. XX в. стал задумываться над проблемой «человек и индустриальный мир», посвятил свои сочинения теме индустриализации, проблеме вытеснения человека-творца, человека-созидателя, распорядителя своей силы, энергии, хозяина собственных желаний. Многие мыслители того времени приходили к выводу, что для индустриализации далеко не всегда требуется человек в его полноте, со всей гаммой чувств и переживаний. Юнгер писал об этом в 30-е гг., предсказывая колоссальное развитие процесса омассовления, своего рода механизации человеческой души, вторжение этого процесса в самые отдалённые уголки и сферы человеческой жизни. Такое развитие влечёт за собой усиление бюрократического начала в жизни общества, распространение бюрократических процедур на все случаи жизни, превращение человека из соучастника, сотворителя в просителя: человек странным образом оказывается в зависимости от каких-то неподвластных ему сил, господствующих над его волей, разумом. Не случайно для героев Юнгера чрезвычайно большое значение имеют сны, в которых раскрываются дремлющие доселе творческие, физические способности человека, обнажаются предназначенные природой глубины восприя- тия его чувств. Человек только в этих снах получает возможность слиться с внешним миром, понимать и чувствовать его.

Герой Юнгера, что хорошо видно на примере такого произведения, как «Беспокойное сердце», это человек, ушедший в сферу мечтаний, в иллюзорный мир сновидений, доверившийся только собственным чувствованиям и интеллектуальным способностям, благодаря которым он распознаёт сущность вещей, глубины происходящего. В общем и целом он занимает позицию, отдалённую от неприглядной реальности. Этот герой существует как бы сам по себе, в безвоздушном пространстве, без каких-либо внешних проявлений своей заинтересованности в этом мире. Жизнь для героя Юнгера только тогда становится жизнью, когда она теряет черты обыденности, заурядности, хотя её цели по-прежнему могут быть неясными, да и вряд ли станут таковыми. Главное - это то, что человек оказался в этом мире и может откликнуться, как пишет Юнгер в «Африканских играх», на мощное притяжение «тёмного и неизвестного», может двигаться навстречу «царству сказочных неожиданностей и приключений». Своё счастье и предназначение такой человек видит в том, чтобы сбросить с себя путы обыденности и отдалиться от привычного [2, p. 10].

Такое магическое представление о мире как о вневременной действительности утверждает себя и сейчас в рационализированном, технизированном мире, не сдаётся перед натиском техники и трезвого расчёта, заставляет видеть вещи в их подлинной значимости, в сокрытой до сих пор полноте. Это, по мнению Юнгера, один из путей познания мира, один из способов вскрытия различных слоёв действительности.

Весьма важная черта в характеристике юнгеровского героя - самоопределение. Например, столкнувшись с серьёзной, смертельной опасностью, человек испытывает вначале ощущение собственной слабости. Но затем, собравшись с духом, преодолев это ощущение, он становится сильным, готовым к осуществлению невозможного [1, p. 3]. Человек вообще не может быть уверен в своей будущности, 
вернее, в прочности того, что его окружает, сопровождает в жизни. Чувство безопасности чаще всего обманчиво. Сложности и трудности возникают неожиданно, застают врасплох, как туман в горах. Бывает и так, что тот или иной человек распознает опасность, но не вступает в рискованную для себя игру, готовится вести длительную борьбу, нисколько не рассчитывая при этом на победу, а, наоборот, осознавая неизбежность проигрыша [1, р. 99]. Отсюда следует, что каждый человек в значительной степени является творцом самого себя. Причём для Юнгера не представляло особого интереса перечисление каких-то отдельных качеств личности, из которых впоследствии можно сложить единый образ. Человек для него уже был единым и цельным, но для кристаллизации этого пока ещё сырого материала его необходимо было пропустить через цепь испытаний, поместить в поле высоких напряжений, высоких энергий, привести его к эмоциональному насыщению. Каким образом намеревался Юнгер осуществить эту задачу, какими средствами рисовал он образ «истинного человека»?

В задачу Юнгера входило представить тип человека - искателя приключений, «беспокойного сердца», который не приемлет спокойный, размеренный, привычный ход вещей в пределах сущего. Такой человек рассматривает жизнь как мозаику из великого множества снов, где каждый из этих снов раскрытие действительности. Этот человек черпает свои духовные и моральные силы из каких-то таинственных источников и уверен в своём предназначении строителя невиданного до сих пор мира, строительство которого, правда, откладывается на неопределённое будущее, ибо прежде нужно разрушить старое.

Герои Юнгера внутренне порывают с обществом и набирают энергию, для того чтобы разорвать также внешние связи. Вместе с тем вовсе нельзя говорить о том, что критическое отношение к современности, к сущему - это есть проявление враждебности по отношению к нему. Признание того факта, что человечество достигло наиболее глубокой отметки на пути своего падения, не означает, что само человечество лишено перспективы. Нужно искать подходы для более полного выявления этой перспективы, для её развития. Размышления в этом направлении характерны для произведений Эрнста Юнгера, особенно для более позднего периода его творчества.

Если говорить о ранних произведениях этого автора, то желание его героев ставить свою жизнь на карту, оказываться в гуще военных событий, в сердцевине битвы есть не что иное, как бегство от забот, сомнений, неясностей повседневности, от необходимости решать тысячи вопросов, искать правильные ответы в паутине житейских взаимосвязей, общественных проблем. Такого рода героизм - это героизм человека, испытывающего страх перед жизнью. Это игра со смертью из страха перед сложностями жизни, перед её непонятностью. Это заигрывание со страхом, попытка уберечься от необходимости проявить истинное мужество, которое, может быть, заключается в том, чтобы быть на высоте требований, предъявляемых судьбой, в каждодневной, неприметной жизни.

Иное дело на войне. Война со всеми её ужасами, страданиями, преступлениями против человека (герои Юнгера, правда, считают, что война сама по себе есть оправдание любых действий) интерпретируется Юнгером как приключение, как явленность человеку таинственных сторон жизни. Это испытание человеческих качеств, так же как лучшие, наиблагороднейшие стороны человеческого характера проявляются, например, в условиях голода. Легко быть благородным за праздничным, богато убранным столом. Нужда и опасность срывают с человека всё благоприобретенное, навязанное воспитанием, оставляя только то, что присуще именно ему [3, p. 73]. Война с её особенностями и требованиями давала возможность проявиться героическим качествам человека, позволяла ускорить процесс его воспитания «изнутри», когда человек стремится обрести качества героя, умение, преодолевая страх, испытывать счастье, рассматривать смерть как торжество жизни, самого себя оценивать как самостоятельную, автономную личность, проявляя полную лояльность и подчинённость руководству, командованию. Неизбежность и необходимость войны, как это следует из сочинений Юнгера, заложены в человеческой природе. Война, конечно, ужасна сама по себе, но она есть элемент судьбы, необходимая составная в ходе мировой истории, необходимая в смысле благотворного влияния на становление нации [4, р. 174]. Очевидно ведь, что вожделенное отношение к природе, к достижениям людского разума, восхищение творениями человеческих рук непосредственно сосуществует с «дикой жестокостью». Человечество знает времена, когда размеры разрушений едва ли держатся в пределах каких-то границ [4, р. 114]. Человек, собственно, есть нечто большее, чем хищник. Он - хозяин, распорядитель и главарь хищников.

Первые произведения Юнгера, для которых особенно характерно воспевание героического, посвящены описанию его военных переживаний, осмыслению военного опыта, раздумьям над поступками и чувствами человека, оказавшегося в экстремальных условиях боевых действий. Юнгер описывает войну как такое событие, участники которого потеряли многое, а может быть, почти всё. 


\section{Филология: научные исследования 3(19) • 2015}

Но всё же это событие оказалось для них благоприятной, великолепной возможностью для формирования личности, лепки характера, для развития героических черт в человеке. В войне как в факте, как в чрезвычайном событии скрыт, по его мнению, смысл нашего времени: это выход из однотонности бытия.

В войне как в событии для Юнгера важны прежде всего переживания человека, её непосредственного участника. Раскрытие этого не ставилось в какую-либо зависимость, от тех целей, которые эта война преследовала. Правда, в своём следовании этому замыслу Юнгер не всегда последователен, ибо весьма сильны в его книгах националистические моменты, стремление развить в своем герое национальное чувство, подчеркнуть, что это была «великолепнейшая армия», которая боролась за величие Германии, а в самом войсковом героизме, фронтовом братстве проявлялась и воплощалась идея единства народа, бесклассовости [3, p. 11].

Во многом, если не во всём, наблюдения, описания, размышления, выводы Юнгера обусловлены его собственной жизненной судьбой, строятся на автобиографическом материале. Дело в том, что разразившаяся первая мировая война, а вместе с ней ожидание великого, сильного, праздничного оказала на Юнгера и многих его товарищей наркотическое воздействие, они оставили всё из прежней жизни и целиком отдались войне. Сам Э. Юнгер добровольно, в первые же дни первой мировой войны оказался в кайзеровской армии и в боевые действия окунулся как в необыкновенное приключение. Это приключение он расценивал в высшей мере положительно, никогда не усомнившись в правильности своих действий, в правильности приказов, которые приходилось выполнять. На фронте он был много раз ранен и неоднократно награжден за личный героизм, в том числе высшими орденами кайзеровской Германии.

Война с её сверхчеловеческим напряжением, смертью и героикой, обострённостью чувствований и восприятия существовала для него именно как событие, как некий порог в становлении человеческого характера, ощущающего потребность в самопожертвовании воителя, лишенного страха и сомнений; цели войны и военные успехи не имели какого-то довлеющего над ним значения. Об этом даже не стоило задумываться. Главное - участие в этом «приключении», в чрезвычайно интересном и сложном испытании, которое выпало на долю человека по велению свыше, было наложено на него самой судьбой. Свист пуль для героя Юнгера - это музыка высших сфер [2, p. 10].

Юнгер неоднократно подчёркивал, что им и его товарищами двигала неуемная жажда необыч- ного, тоска по нему, стремление к «великим переживаниям», воодушевлению, которое до сего события заглушалось бытийственностью в пределах материалистического пространства, однообразием повседневности. Иными словами, героика, в ореоле которой пребывали персонажи Юнгера, была не чем иным, как производным от повседневной тоски или даже страха. Это был результат стиля жизни, черты которого вполне идентичны мазохистским. С началом войны в сознании Юнгера и его героев крепла убеждённость, что судьба распорядилась так, чтобы человек явил миру свои лучшие качества, в данном случае качества героя.

Возможно и необходимо это было потому, считал Юнгер, что человеческая душа в современном мире посреди хаотичных нагромождений, внутри переплетений света и тени наполнена надеждой и отчаянием, согласием и неприятием, пониманием и отклонением. Возникающий у героя Юнгера страх преодолевается ещё большим стремлением к переживанию боли, страданий. После прохождения через более выраженные страдания, через боль возникает чувство освобождения, ироничного отношения к прежним страхам.

Героя Юнгера, испытывающего тоску в условиях обыденности, не интересовала действительность сама по себе, её конструктивные параметры и особенности, её устройство со всеми взаимосвязями и тенденциями. Главным для него было ощущение того, что он есть продукт неких живительных природных сил. Он участвовал в войне, повинуясь зову судьбы, велению вселенского рока, направлявшего людей на переустройство мира. В ходе боевых действий его также не покидало ощущение того, что он сам и его возмужавшие, набравшиеся боевого опыта товарищи скорее позволят уничтожить себя физически, но не станут терпеть участь побежденного. Смерть в постели это не судьба воителя. Его место на поле битвы, где посредством борьбы и гибели рождаются новая жизнь и новый дух [3, p. 91].

Герой Юнгера в постоянной готовности к борьбе и смерти: в самой смерти видит зачаток новой жизни, в самом себе - носителя великой силы. Прежде чем погибнуть, такой герой, член когорты наилучших, наихрабрейших, достойнейших, кто снискал любовь Земли, из самого факта, события собственной гибели намерен устроить празднество, которому будут салютовать орудия всего мира. Это будет невиданный и неслыханный прежде салют. Военные повествования Юнгера - это апология элиты, прославление возвышающихся над массой.

Юнгер воспевает такие качества, как абсолютное послушание и терпение по отношению к страданиям и лишениям. Впоследствии, для такого 
человека чужая человеческая жизнь утрачивает всякое значение, лишается какой-либо ценности: им овладевает желание убивать, участвовать в охоте на людей. Наша работа - убивать, пишет Юнгер, и наш долг - делать эту работу хорошо. Таким человеком управляет не разум, не чувства, а какие-то глубинные, уходящие в истоки человечества первожелания, доныне подавленные культурой, цивилизаций и лишь теперь, с войной как даром судьбы оказавшиеся на свободе. Лишь почувствовав кровь, ощутив её запах, утолив эту «пражажду», солдаты вновь обретают трезвость и ясность мысли, способность воспринимать новые задачи.

Юнгер далее пишет, что, несмотря на все достижения человеческого разума, науки и техники, сам человек остаётся в глубине своей «нагим и грубым», как его предки, обитавшие в лесах и степях. Именно в военных условиях человек проявляет свою истинную сущность. «Истинный человек» навёрстывает упущенное, оказавшись в обстановке пьянящей оргии. Его желания, подавляемые обществом и законами, выходят наружу, становятся единственным и святым, последним разумом. В человеке просыпается «таинственное чудище» и во весь рост встаёт из глубины его души. Отныне человек, отринувший ценности цивилизованного мира, воспринимает себя как венец творения, как эталон личности, испытывает гордость за самого себя. Такой истинный человек, т.е. то, что образуется из сплава немногих первоначальных желаний, импульсов, являет себя миру во время «танца на острие клинка», в момент пребывания между бытием и небытием.

Многообразие жизненных форм и содержаний упрощается до одного-единственного смысла: борьба, постоянный риск, балансирование на грани гибели. По отношению к борьбе, на фоне её сущностных сторон все в этом мире утрачивает свой смысл, становится незначительным и ничтожным, низведено до уровня животного существования. Борьба существует вечно, это «высшее решение». Поэтому в посюстороннем мире заслуживает уважения прежде всего тот, кто ближе всего стоит к врагу, не скрываясь от действий за внешними проявлениями романтики.

Но, как отмечает Герда, Либхен, нельзя пройти мимо замечания Юнгера о том, что человек со всеми своими героическими чертами с ужасом чувствует и понимает, что его ум, разумность, его способности и достоинства, как физические, так и духовные, ровным счётом ничего не значат, выглядят смешными, никому не нужными атрибутами. Однако этот же человек понимает, что над ним довлеет чувство долга и чести; именно он должен сделать то, что от него требуется, перебороть страх и ненужные размышления. Превыше всего следует расценивать долг и честь, воспитывать людей в этом духе, готовить соответствующий человеческий материал, т.е. люди рассматриваются как сырьевой продукт, из которого можно готовить нужные изделия. Чем качественнее «изделия», чем подготовленнее материал, тем меньше они задаются вопросами зачем, для чего. У людей в таком случае не возникает никому не нужный страх по поводу утраты своей индивидуальности. Юнгер пишет о причастности людей к общей судьбе, об их органическом включении в круговорот природы, о службе сокрытому целому $[4$, p. 41].

Всё в мире взаимосвязано, взаимообусловлено, а именно: становление, существование, угасание - как в едином природном организме. Иными словами, сам природный механизм не оставляет человеку ничего иного, кроме готовности совершать героические дела, бороться за собственное существование, обеспечивать условия для своего становления, сохранять покой и уверенность на закате жизни. Всё предопределено в человеческой судьбе, и все попытки распознавания истины, полагание, будто в этом направлении сделан какойто шаг, означают не что иное, как познание своего собственного, заложенного ранее стиля, предопределённого судьбой.

Героическое деяние как основу действий человека Юнгер по-прежнему оставляет на господствующей высоте. Ничего нет более важного в этой жизни, чем героика. Но подобная жизненная установка увязывается у героя с его неосознанной привязанностью к некоему единому общему, целому, к судьбе. Сама война есть естественная необходимость, она рассматривается Юнгером как явление, обусловленное самой природой. Войну как явление не стоит отрицать, ибо она тогда поглотит всего человека.

Но при всей своей героичности человек не лишён чувства страха, которое возникает особенно тогда, когда этот человек обращается к «ненужным» мыслям. В 30-е гг., с выходом «Рабочего», персонажи Юнгера как бы понимают, что индивидуальная героическая деятельность не принесёт победы, что она связана с гибелью. Наступило время безымянности, включения в общее дело, затерянности в массе.

Анализируя процесс технизации военных действий, Юнгер говорит о наступлений эпохи «технической деловитости», которая требует изменений в самом человеке, взывает к обретению им нового облика, формированию «нового человека». Сам писатель не ставит перед собой задачу конкретного описания этого «нового человека», ограничиваясь утверждениями о том, что этот человек есть избранный судьбой предвестник нового государства, 


\section{Филология: научные исследования 3(19) • 2015}

которое по необходимости будет подчинено законам и духу технической эпохи. Судьбу, пишет Юнгер, нужно не сносить, не терпеть, а вести, искать её исполнения, выполняя до конца выпавшую на свою долю задачу.

Стремление человека к технизации мира, всей своей жизни - это стремление оказывать непосредственное влияние на ход своей судьбы, заключение свсеобразной сделки с ней в расчёте на то, что вечно, что по необходимости должно погибнуть, погибнет, а другое останется. В любой катастрофе, постигающей человечество, имеется, как полагает Юнгер, свой смысл и обоснованность. На пути же к познанию этой определенности человеческой судьбы самого человека сопровождает страх.

Юнгеру, который распознает ужасы своего времени, в какой-то степени ясна предопределенность в судьбе человека и всего мира, видны пути их дальнейшего развития. Писатель говорит о неизбежной, хоть и через большие промежутки времени, встрече человечества с серьёзными катаклизмами. Как философствующий писатель Юнгер не ограничил себя воспеванием героического. Он осознавал вовлеченность человеческого существа также в такое состояние, как страх, что заставило его обратиться к осмыслению страха как проблемы метафизической, искать ответ на вопрос о том, как же всё-таки объяснить этот страх и тем самым выйти из него, преодолеть его. Мы видим, что герой Юнгера, действующий и переживающий свои приключения в неизвестной для самого себя стране, в подчёркнуто необычных условиях, неизбежно сталкивается со страхом как атрибутом человеческого бытия, чувствований человека. Этот герой вызывает страх у других или испытывает это чувство сам, встречаясь со сценами пыток, убийств.

Мир полон таинственности, вызывающей страх. Юнгер показывает это на примере воспоминаний ребенка, в комнату которого взглядывает Луна, «большая и ужасная». Окутанный лунным светом каждый предмет застывает на своем месте, становится как бы изначально неподвижным, и кажется, что он не способен более возвратить себе качество подвижности. В то же время каждый предмет обретает некие новые, таинственные черты, в нем угадывается желание что-то сказать. Не выражает ли себя этим самым тот «человек на Луне», очертания лика которого мы видим на поверхности земного спутника? Этот человек всемогущ, и ребёнок, пишет Юнгер в «Сицилийском письме человеку на Луне», испытывает перед ним страх как перед существом, обладающим злой магнетической силой. Когда этот человек являет себя миру во всем своём великолепии, на него нельзя долго смотреть, ибо тот, кто это сделает, окажется во власти таин- ственных молчаливых сил, обнаружит себя внутри вымершего мира.

В одной из новелл, открывающих сборник «Беспокойное сердце», Юнгер пишет о том, что полёты человека во сне равнозначны воспоминаниям об имевшейся или имеющейся в распоряжении человека особой духовной силе. Ощущения во время полётов, как и сами полёты, бывают различными: в одном полёте человек может быть расслабленным, выбирать удобную для себя позу, другие - само напряжение. В них человек, суровый и замкнутый, повернувшийся лицом к земле, вытянувшийся в струну, несётся над ночными улицами и площадями, внезапно, как выныривающая из-под воды рыба, появляясь перед одинокими прохожими, которые тут же застывают на месте с искажёнными от ужаса лицами.

Запоминающимся образом во всей этой картине, фрагментом, несущим основную смысловую нагрузку, остаётся именно это как бы высвечивающееся темнотой ночи безмолвное, напряжённое, с широко раскрытыми неподвижными глазами бледное человеческое лицо, не принадлежащее какомуто опредёленному человеку. Это лицо вообще. Искаженное страхом, оно застыло на фоне всего земного шара как человеческой обители.

Сформировавшаяся таким образом в сознании человека картина олицетворяет собой ощущение времени, сопровождающее жителя Земли в его одиноком путешествии через заброшенный неосвещённый мир. Это ощущение - страх. Дело вовсе не в том, что кто-то, оказавшись в данный момент на безлюдной тёмной улице, неожиданно для себя столкнулся с чем-то ранее немыслимым, что вызвало у него ощущение ужаса. К проявившемуся в данный момент состоянию человек шёл издалека и давно. То, что сопровождало человека, сосуществовало с ним и находилось в нём самом, вышло из темноты совместного существования, приблизилось к нему вплотную, глянуло в лицо и привело своего визави в оцепенение.

Это не просто момент физического состояния человека: в нём отображены более широкие аспекты человеческого бытия, героика поступков и романтика поисков, творческий полет духа, свобода фантазии, способность удивляться и восхищаться, воспринимать нечто большее, чем предметный мир. Однако всё это оказывается лишь фоном, на котором разворачивается драматичная в своей последовательности событийная цепь действительной жизни. Человек, в сущности своей герой, мечтатель и романтик, искатель приключений, который «глубину жизни», её сущностный смысл зачастую склонен воспринимать как «радужную оболочку мира», вдруг посредством этой «оболочки», через 
её знаки, символы как бы пробирается к восприятию тайн жизни. Юнгер пишет о немецкой душе как чрезвычайно тонком, восприимчивом инструменте с невообразимой глубиной восприятия, вступающей в контакт со всем сущим, являющимся из этих глубин. Что, помимо восприятия героического, характерно для таких персонажей Юнгера?

Прежде всего они лишены прочных социальных связей, не воспринимают себя частью единого социального организма, действуют в одиночку среди других одиночек, переживают необычные состояния, находятся во власти неординарных обстоятельств, фантастического окружения. Такой человек не может быть уравновешенным в уравновешенном, благочинном обществе, потому что, как заявляет один из персонажей «Африканских игр», он слишком привык к солнцу [2, р. 73]. Но что примечательно?

Всё сопутствующее, сопровождающее этих людей в их наполненных новыми впечатлениями путешествиях, не захватывает, однако, до такой степени, чтобы человек мог освободиться от ощущений тревоги, страха, доходящего до ужаса. Жизнь воспринимается как стремительное пролетание через кипу пробиваемых падающим телом металлических листов, издающих при этом оглушающий шум, который неотвратимо сливается в сплошной грохочущий громоподобный звук, разрывающий в конце концов границы сознания [1, p. 15]. В таком нарастающем темпе человека охватывает страх, превращающийся в ужас, и это состояние несовместимо с ощущениями испуга, боязни, опасения. Это безжалостно, жестоко овладевающее человеческим существом ощущение ужаса, возникающее не на почве каких-либо предположений, догадок или опасений, а как результат прямого соприкосновения с его источником; это встреча со взглядом медузыгоргоны. Страх как боязнь ещё оставляет человеку какую-то надежду на благополучный исход, на возможность диалога. Страх как испуг - свидетельство начала падения, результат восприятия звука от разрыва первого металлического листа. Затем следует стремительный полёт, падение под грохот металла как леденящее душу подтверждение приближающегося ужаса. Догадывается ли человек, что его жизненный путь - это пространство, располагающееся между познанием, умовосприятием гибели, упадка и самой гибелью, распадом, нисхождением в небытие?

Догадывается ли человек, который, согласно Юнгеру, способен к восприятию тончайших природных, физических явлений, к так называемому «стереоскопическому восприятию», когда ему приоткрываются таинства вечного, когда под влиянием силы человеческого духа открываются невидимые остальным пути познания мира, что происходит в этом пространстве, через которое, вероятно, его пронесет жизненная волна?

Или в том мире, в котором обнаруживает себя человек, пробивает дорогу иная тенденция, а именно имеющая своим содержанием то, что мир, вещи, предметы в нём, сама жизнь располагают собственным голосом, сокрытым от человека. Если бы человек мог не просто слышать, внимать этому голосу, он обладал бы удивительными способностями. Но человек, создав машины, отдается во власть представлениям о собственном могуществе, воображая, будто он может «подоить Вселенную» [1, p. 151].

Ощущение ужаса нарастает с проистеканием жизненного потока. В человеческой природе - постоянное ощущение беспокойства, нехватки, недополучаемости чего-то. - Например, человек испытывает полновесное ощущение сытости только тогда, когда перед его глазами больше продуктов, чем он может усвоить на данный момент. Многие люди, массы людей не располагают такими условиями. Им постоянно чего-то не хватает. Они воспринимают свою жизнь как балансирование между благополучием и нуждой. Жизнь под угрозой катастрофы $[1$, p. 52]. Вряд ли можно укротить нужду. С количеством продуктов растет количество едоков, с приростом новых сил повышается готовность к войне.

Нас независимо от того, находимся ли мы внутри мира или вне его, в глубине или на поверхности, охватывает боль того, кто отворачивается от благостных, заманчивых в своём великолепии вещей, куда бы он ни двинулся, куда бы ни обратился. Мы впадаем в состояние беспокойства и не выходим из него ни в минуты одиночества, ни во время участия в праздничных пиршествах мира [1, p. 10].

Юнгер, таким образом, вовлекая человека в мир иллюзий, не пытается внушить ему какие-то ложные надежды. Не его задача переубедить людей в истинности или ложности библейского положения о том, что для жителя Земли уготованы ужас, яма и петля. Скорее, как автор, как мыслитель, Юнгер исходит из этого положения как отправного. Для него становится практически очевидным, что человек, переживающий различные состояния духа, находится внутри страха и страх присутствует в нем самом. Такой человек настолько сжился со страхом, до такой степени научился воспринимать его как некую данность своего бытия, обязательность чувствования, что его, например, нисколько не шокирует такой факт, как продажа в мясной лавке частей человеческого тела. Напротив, персонаж Юнгера спокойно вступает в беседу с продавцом и обсуждает способы приготовления блюд из этого «продукта». Если говорить об оценке этого собы- 
тия, то все, на что хватает юнгеровского героя, сводится к реплике о том, что цивилизованный процесс в этом городе шагнул далеко вперед [1, p. 12].

В устах героя это замечание носит оттенок иронии, не более того. Цивилизация как уничтожение человека, превращение его в объект охоты, в товар для мясной лавки образ весьма откровенный и прямолинейный, но чрезвычайно сильный и впечатляющий. Юнгер, прибегнув к нему, вольно или невольно выражает свой собственный страх перед цивилизацией. Чувство опасности, которое как бы приглушено у непосредственного героя иронией, усилено отношением автора к данному эпизоду.

Страх, таким образом, оказывается постоянным атрибутом человеческого бытия. Вместе с тем Юнгер предупреждает, что ни в коей мере не стоит принижать человека; ибо каждый из людей способен подняться на доступную ему высоту, познать ту или иную истину. Кроме того, все равны перед лицом смерти, перед её постоянно открытыми вратами. Человек не только боится потерять жизнь, но боится быть обманутым в своих чувствах. Он хочет отойти от материального и обрести чувство уверенности и защищённости в сферах духовного. Духовное обретает для него черты основания мира, его фундаментальной опоры. Человек испытывает не просто благоговейные, трепетные ощущения перед загадками времени, полными тайн глубинами бытия, бесконечными далями мира, красочностью окружающей его Вселенной. Уже сама цветовая гамма вызывает у человека различные чувства: голубой цвет приносит успокоенность, красный цвет вносит ускорение в дыхание жизни, а вместе с ним и ощущение страха. Этот цвет символизирует разделённость мира, раскол, поляризацию. Между этим цветом и человеком нет пространства для размышления: он требует человека всего и сейчас [1, p. 157].

В таких условиях постоянного преследования уйти, спрятаться от страха - это, видимо, одно из основных желаний человека. Но страх, охватывающий его, например, во время сновидения, не проходит, и к тому же оказывается, что это уже вовсе не сон, что все происходит наяву. Вообще грань между реальностью и иллюзорным восприятием мира у Юнгера не просто расплывчата, а стирается, исчезает. Писатель сам говорит о том, что ему с трудом удается различать осознанное и неосознанное собственное существование, т.е. ту жизнь, которая рисуется ему во сне, и действительную. Сон - это способ более глубокого познания мира.

Всё происходит наяву и не наяву: реальные переживания, восприятие реальности сливаются с видениями во сне, с тем, что грезилось. Но весьма реальным остаётся нечто, вызывавшее и вызыва- ющее страх, нечто, что нельзя идентифицировать, определить как действие и как предмет. Это нечто существует и воздействует на психику, на поведение человека. За всем этим таится некто другой, иной или иное, и ощущение присутствия этого можно выразить испуганным восклицанием «чужой в городе». Внезапно оглянувшись, можно обнаружить этого чужого у себя в комнате и застыть от ужаса, от невозможности предпринять какие-либо действия. В сознании останется лишь нечто, некая фигура, неотрывно преследующая тебя горящим взглядом все увеличивающихся пронзительных глаз, в которых таится угроза. В конечном итоге на тебя смотрят уже не глаза, а ты остаёшься один на один с пустыми, черными глазницами, оказываешься один на один с «абсолютным Ничто», которое скрывается за последним пологом ужаса [1, p. 16]. Поэтому, видимо, не случайно Юнгер пишет о единственно верной, как ему кажется, позиции - о дистанцировании от всего, что окружает человека, о пребываний в этом мире в качестве обособленного существа.

Способен ли человек распознать глубинную суть жизни с её внешне видимым распределением ролей, когда одному выпадают на долю мучения, другому - роль мучителя, третьему - место надсмотрщика-распорядителя? Ничто не сможет спасти человека от этих «даров судьбы». Как ему вести себя, когда станет ясно, что жизнь - это своего рода «тайный замок боли» [1, p. 26]. Откуда взять силы, чтобы оказаться на высоте положения, чтобы преодолеть это? Ведь сам человек, согласно Юнгеру, проявляется в том, что его песня - одновременно восхваляющая самого себя и тут же умоляющая, робко шепчущая [1, р. 172].

Современный человек, пишет Юнгер, родился и живёт в такое время, когда ему; с одной стороны, угрожает холодная деловитость, безразличие, а с другой стороны, всё более чётко обозначающаяся, усиливающаяся жестокость. Этот человек, как между Сциллой и Харибдой, вынужден плыть между войнами и гражданскими войнами и даже не знает, каким именем обозначить те события, то явление, внутри которого он оказался, в чьи сети он попал [1, p. 161].

Из размышлений и наблюдений героев Юнгера следует, что человек живёт в двойственном, лишённом твёрдых очертаний мире. В этом мире постоянно меняются краски, что вызывает обеспокоенность у наблюдателя. Если же у людей не отмечается этой обеспокоенности, то тогда возникает страх по поводу того, что некто, один из многих испытывает чувство сопричастности игре таинственных сил.

Двойственность мира проявляется, например, в изменяющемся облике того города, в котором 
оказался герой Юнгера: днём это неухоженные, бесприютные улицы, заполненные измождёнными, безрадостными, плохо одетыми людьми, женщинами, стоящими в длинных очередях за хлебом. В ночное время все облупившиеся, потрескавшиеся жалкие фасады зданий увешаны гирляндами огней, что создаёт впечатление дворцовых ансамблей; открываются многочисленные танцзалы, рестораны, кафе, в которых звучит действующая на нервы музыка, собирается публика, бравирующая своей нарочитой элегантностью; буфеты заполнены исключительно омарами и дичью с трюфелями [1, p. 4].

Двойственность положения человека в мире проявляется также в том, что сам мир выступает как машина: завораживающая, привлекающая своей отлаженностью машина. Нет никого и ничего, что не было бы вовлечено в процесс труда. Управляя этими машинами, человек имеет, как ему кажется, все основания для того, чтобы чувствовать себя хозяином мира, управляющим природы. Одновременно с этим чувством он испытывает другое, а именно пребывания в экстремальной обстановке, нахождения в боевых условиях в момент свершения важных событий. Точное представление об этой боевой обстановке конкретному человеку трудно получить, потому что её условием является одиночество, которое к тому же всё сильнее маскируется внешне коллективным характером нашей эпохи. Но человек выбирает свой путь, своё место сам, он не избегает, не уклоняется от этого «великого процесса», и сама эпоха находит его готовым к восприятию именно такого хода вещей [1, p. 56].

Но то, с чем изъявивший свою готовность человек встречается, трудно описать: видимо, полагает Юнгер, это общее ощущение, которое свидетельствует о том, что воздух постепенно накаляется, всё более обжигает. Не остаётся никакого выхода «стальная змея познания» приведена в движение. Труд человека под воздействием его собственных рук, при его непосредственном участии ожил, обретя невиданную мощь и власть. Лицезрение этой мощи моторов и машин наполняет человека тайной гордостью, но вовсе не чувством победы [1, p. 57].

Шум моторов, движение машин, демонстрация силы и мощи техники - это лишь некая видимость того, что должно называться жизнью. Это явление, которое призвано убедить всех в том, что за ним стоит нечто значительное, живое. На самом деле это не так: это обман, за ним ничего нет, и именно это вызывает беспокойство у человека.

Человек прячется за внешние формы своего бытия, дающие представление о благополучии, спокойствии, уверенности. Со скучающим безразличием он передвигается в создаваемом им самим пространстве вещей, условностей, понимая, что от- каз от внешней атрибутики повлечёт за собой цепь вопросов и открытий. Нынешнее показное равнодушие человека - это не что иное, как страх. Люди ощущают его постоянно, потому что нынешнее благополучие и благолепие есть лишь фасад, приукрашенная передняя, откуда путь ведёт в преисподнюю, в пыточную камеру [1, р. 79].

Человек живёт в состоянии страха, опасения за свою судьбу ещё и потому, что он не хочет раскрывать тайны, не хочет обнародования своеобразного тайного договора, о котором неизвестно, был ли он заключён самими людьми и с кем, неизвестно когда это было сделано, но известно, что этот договор оказался достаточно прочным. К раскрытию этой тайны можно добраться, ответив на вопрос о том, что есть человек, в какой степени ему присуще чувство «внутреннего стыда» и ответственности. К чему предрасположен человек? Предрасположен ли он к чёткой, упорной, кропотливой, лишённой внешней эффектности работе или он испытывает потребность в создании ажиотажа вокруг себя, требует выхода на ярмарочные площади, не интересуясь конечным результатом, полезностью своей работы. Юнгер становится ещё более резким в своем вопрошании, пытаясь выяснить, не является ли человеческое общество скопищем зверей? Постановка этих вопросов и поиск ответов на них вызывают у людей боязнь, они чувствуют, что за всем этим скрывается некая тайна, и если она вдруг действительно приоткроется, то не окажется ли это открытие опасным для самого человека? Как в таком случае быть, какие действия предпринимать и стоит ли тогда думать о нравственности, о моральной оценке этих действий, о последствиях и т.д.

Человек не может судить сам о себе: он не знает себя. Если он видит себя в кино, собственное лицо кажется ему незнакомым, движения чужими, голос не своим. Человек не может судить о самом себе. Он не может, если он, например, писатель, определить свой стиль; как врач, он не может сам себя лечить. В общем, каждый склонен расценивать свои достижения как хорошие: любая женщина считает себя красивой. Человек ощущает свою идентичность со слепой волей, с неоформленной жизненной силой, которая заполняет его, но то особенное, чем располагает человек, а именно его жизненный стиль, можно распознать только снаружи, созерцая все это извне. Однако же человек может выйти из-под этого влияния, может достичь высочайшей степени «просветления» в понимании жизни, в осмыслении порядка, в том числе и самого себя он может увидеть со стороны. Эти черты присущи развитому праву, государству, историческим описаниям; это основные, сущностные источники для верховной попирающей народ власти. Они необ- 


\section{Филология: научные исследования 3(19) • 2015}

ходимы для общества, для человека, для ликвидации его слепоты, для выхода из состояния просто сосуществования рядом с другими, неотличимыми ото всех [1, p. 124].

Всё в мире подчинено определённому порядку, движется в пределах чётко обозначенных траекторий, маршрутов. Создаётся сеть из этих траекторий отдельных воль и желаний, сеть, в которой чётко явлена миру распределённость насилия и порядка. Удивительно, что любое сумасшествие, сумасбродство находит столько помощников, сколько ему нужно и сколько хочется. Но так как, несмотря на это, наш мир продолжает идти своим путем, можно не сомневаться, пишет Юнгер, что он упорядочен на основе «высокого плана» [1, p. 142].

Наблюдая за движением птиц на птичьих базарах, прослеживая их полеты в сторону моря и как бы исчезновение в бесконечном, а затем их возвращение словно из пустоты, можно услышать своего рода первомелодию, в которой звучит «смелая, отважная двойная игра духа», захватывающая человека, овладевающая им и вместе с тем глубоко сокрытая. В чём двойственность этой игры? Юнгер пишет, что в ней, с одной стороны, видно стремление к наивысшему, «металлическому» выражению сознания, к приданию ему чеканности. С другой стороны, эта игра уводит в «дикие зоны элементарного насилия», ведёт к растворённости в этих зонах [1, p. 95].

В этих двух тенденциях, двух склонностях, так резко уходящих друг от друга и, как кажется, противоречащих друг другу, словно сон, иллюзия и действительность, скрыто единство и многообразие нашего удивительно загадочного мира. Это проявляется во всех коллизиях сегодняшнего дня, во всех теориях и значительных явлениях, даже в характерах неординарных личностей, стоящих над другими. Ничто другое так не характерно, не примечательно для вас, как это сосуществование ужасной, развязывающей силы и неподвижной смелости созерцания. Это, подчёркивает Юнгер, наш стиль, стиль «вулканической точности», своеобразие которого ещё не распознано [1, p. 95].

В периоды, когда общественным организмом начинает овладевать недуг, когда начинают расшатываться общественные устои, тогда проявляют активность силы или люди, «питающиеся» мучениями других, накапливающие на чужих страданиях свою собственную энергию; эти люди выходят из тёмных углов, в которых они пребывали до поры до времени, и стремятся к установлению более или менее опирающегося на мысль, рассудок, здравый смысл, но всегда организованного на принципах, господствующих в мире животных, деспотического режима [1, p. 60]. Причём в оправдание своего деспотизма они наделяют чертами животных тех, кого сами стремятся уничтожить.

Этим желаниям может противостоять тот тип поведения, при котором проявляется благородство и достоинство. Эта благосклонность к сущему тесно связана с порядочным в человеке, с его свободой и силой. Эти качества были заметны ещё в героях Гомера. Здесь представляет себя духовная, основанная на добрых истоках сторона власти, символом которой является не пурпурная мантия, а жезл из слоновой кости $[1$, p. 60]. В этом случае создаются наилучшие условия для общественного развития и жизни человека, для процветания нравственности, без каких-либо затруднений взрастают и развиваются «образы и формы». Особенно благоприятны для такого развития небольшие города, в которых не исчезает человек. Человеческая память сохранила образцы такого жизнеустройства (например, Афины времён Перикла: этот свет из прошлого преодолевает столетия, не ослабевая, невзирая на неблагоприятное развитие последующих времен). Поэтому одной из форм противостояния разрушительному в человеке, в обществе, в мире должно стать собирательство, создание музеев, попытки найти в предметах или каких-либо иных упоминаниях о древности то внутреннее ядро жизни, ту божественную силу, которая живёт в нас. Человек чувствует себя осчастливленным, когда он слышит, пусть хоть и слабый, но отклик из глубины тысячелетий, из загадочных исторических пространств [1, p. 116]. Юнгер воспевает человеческий дух, ясный разум, ведущий к цели через все препятствия, ужасы и страхи даже вопреки сопротивлению богов.

Вместе с тем вряд ли когда-нибудь можно будет понять дикую и беспорядочную сменяемость картин нашей жизни: мы как будто движемся в этом мире через огромный, титанических размеров город, который в одном месте освещается огнем ужасных пожаров, в то время как в другом месте рабочий люд занят разметкой будущих гигантских отроек. Эта калейдоскопическая смена картин глубокого, тяжкого страдания, имеющего место как бы во сне, и «демонической неранимости» сознания, стойкости духа, который подчиняет хаос своему влиянию, создает искусственный противовес экономическому и техническому опустошению. Можно догадываться о наличии точек соприкосновения, сближения и «вплавления» друг в друга этих двух мотивов, об их «тайной связи». Можно предположить, что здесь укрывается метафизическая часть задачи, выпавшей на долю людей $[1$, p. 95, 114]. В городе ужасов, уничтожения человек способен выстоять только в том случае, если он обладает таким «божественным вооружением», каким являет- 
ся веселость как особая форма непосредственности в обращении с властью [1, p. 97].

С ощущением неизбежной и грозной опасности, надвигающейся гибели жизнь обретает новые краски, неизвестную до сих пор прозрачность, просматриваемость. Очертания сложившихся порядков делаются чёткими и различимыми, а повседневное, привычное обретает черты особого благородства, достоинства, как бы поднимается на более высокую ступень. Человек в этих условиях особой, «повышенной зрячести» начинает действовать сообразно тому значению, которое придано ему как творению природы или бога. Он в меньшей степени обращает внимание на необходимость просто сохранить себя; принять смерть в этих условиях осознаваемой гибели - это значит сыграть свою роль «сакрального свидетеля», оказаться достойным этого момента и надеяться на благосклонность высших сил. Жизнь получа- ет своё разрешение в экстремальных ситуациях, в борьбе до последнего на проигранной позиции, когда человек, завязанный на самого себя, без приказа, не имея ясного представления о сложившейся обстановке, до конца исполняет свой долг. Такая жизнь сравнима с теми процессами, когда какое-либо вещество помещают в зону высокого давления и под этим давлением возникают кристаллы, в формах, которых олицетворена, явлена материальность мира [1, p. 100-101].

Спокойствие и уверенность человек обретает перед лицом смерти, когда его внутреннему взору, как географическая карта, предстает план его собственной жизни с чётким изображением. Человек видит не только внешнюю сторону этого плана: до него доходит сама суть, глубина замысла, содержания этого плана. Этому человеку становится доступным содержание жизни и содержание смерти: его ничто более не страшит [1, p. 119].

\section{Библиография:}

1. Junger E. Des abenteuerlicke Herz. Frankfurt a. M. : Ullslein, 1972.

2. Junger E. Ausgewehlte Erzahlungen. Stuttgart: Klett, 1985.

3. Junger E. In Stahlgewiffern. B.: Mittler, 1940.

4. Liebchen G. Ernst Junger t Seine lit. Arbeiten in den zwanzigerJahren: EineUnters. zuges. Funktion von Lit. Bonn: BouvierYerl. (Grundmenn), 1977.

5. Wandlung und Wiederkehrs Ernst Jungerzum 70.Geburtstag / Hrsg. von Arnold H.L. Aachen Verl. Kritik (Georgi), 1965. $246 \mathrm{~S}$.

\section{References (transliterated):}

1. Junger E. Des abenteuerlicke Herz. Frankfurt a. M. : Ullslein, 1972.

2. Junger E. Ausgewehlte Erzahlungen. Stuttgart: Klett, 1985.

3. Junger E. In Stahlgewiffern. B.: Mittler, 1940.

4. Liebchen G. Ernst Junger t Seine lit. Arbeiten in den zwanzigerJahren: EineUnters. zuges. Funktion von Lit. Bonn: BouvierYerl. (Grundmenn), 1977.

5. Wandlung und Wiederkehrs Ernst Jungerzum 70.Geburtstag / Hrsg. von Arnold H.L. Aachen Verl. Kritik (Georgi), 1965. 246 S. 